\title{
On the Past History of the Ferns.
}

\author{
BY \\ E. A. NEWELL ARBER, M.A., F.L.S., F.G.S. \\ Trinity College, Cambridge; University Demonstrator in Palacobotany.
}

With a Diagram in the Text.

$\mathrm{U}$

NTIL quite recently the belief has been current that, in the Palaeozoic period, and more especially in Carboniferous times, the True Ferns were sufficiently abundant to form one of the more characteristic groups of the then existing vegetation. Also that, of the two great divisions, the Eusporangiatae were, at that period, by far the most numerous and diversified. In the light, however, of recent Palaeobotanical research on the nature of the fructifications of the Cycadofilices, and other Palaeozoic Fern-like plants, our ideas on this subject are rapidly undergoing considerable modification. The problems connected with the ancestry of modern Ferns have been rendered, if anything, more complex and difficult of solution than before. It is proposed to consider briefly here some aspects of the present position of our knowledge of the Palaeozoic and Mesozoic Ferns.

The point of view adopted will be essentially that of the Geological Record. At the outset, we may distinguish carefully between the problem as to whether a particular race or family was actually in existence during any particular geological period, and the question whether that race had then attained to the position of a dominant ${ }^{1}$ or ruling factor in the vegetation of the day. The former is not always capable of solution, but the latter can be answered with confidence in the great majority of cases.

It will perhaps be helpful in this consideration of the ancestry of modern Ferns to approach the Geological Record in a somewhat novel

1 The term 'dominant' as used here, and in my 'Catalogue of the Glossopteris Flora,' is intended to imply the adjectival sense of 'ruling.' A dominant type is one of several races, which at any particular geological period constituted the more important and characteristic features of that flora. Thus, in the present day flora, among the higher plants, the Dicotyledons, Monocotyledons, Coniferales, and Filicales are the dominant groups.

[Annals of Botany, Vol. XX. No. LXXIX, July, I906.] 
manner, and try first to recognize the particular geological period at which one or other of the main divisions of the Ferns attained to its maximum diversity and differentiation; and then to trace it backwards and forwards in geological time, so far as our present knowledge will permit. As the result of comparatively recent research it is now possible to adopt this mode of attack in respect to the more important elements of those floras with which we are best acquainted, i. e. those of the Palaeozoic (Devonian, Lower Carboniferous, Upper Carboniferous, and Permian) and the typical Mesozoic floras of the Rhaetic, Jurassic, and Wealden. If, during any one or more of these periods, one line of descent was particularly successful in the struggle for existence, there is ample evidence of the fact to be found in the rocks of that age in some geographic region or other. The imperfection of the Record, largely exaggerated in the past, can be wholly neglected where we are considering the larger divisions of the Vegetable Kingdom, such as phyla, classes, or groups of plants. For instance, the Cycadean line of descent was obviously at its maximum in Mesozoic times. This is shown by the abundance of Cycadean remains in the rocks of the Rhaetic, Jurassic, and Wealden, in many parts of the world, as compared with the rarity of such fossils in the Palaeozoic and Tertiary (including Recent) floras (see text-figure I, p. 229).

A study of the broader botanical features of the Palaeozoic and Mesozoic vegetations shows that in the case of a phylum or group which has, at one time or another, been successful, we can often recognize three phases in the line of descent. One such represents the period of the maximum diversity and differentiation, when the race had attained to the status of being one of the dominant factors in the vegetation. The other two, on the contrary, correspond to periods when it was a subsidiary type, and are the stages of adolescence and senility. We can represent these three phases diagrammatically if, instead of indicating by a thin line the record of a phylum or class of plants extending through a number of geological periods, we use a more or less lenticular figure (see text-figure I, p. 229); the breadth of the figure being proportionate to the degree of differentiation of the group. The broad phase of the life-line indicates the periods at which the race was a dominant factor in the then existing vegetation, the thinner lines, those when it was subsidiary to other groups. No doubt the exact form of the life-figure varies in the case of different races; as will be seen from a comparison of that of the Cycadophyta and the Leptosporangiatae indicated in the text-figure on p. 229.

I propose to attempt to recognize here the various phases in the lifelines of the Modern Ferns. In discussing this problem I have found it helpful, if indeed it is not absolutely essential, to consider separately the lines of descent of the Leptosporangiatae, Eusporangiatae, and Hydropterideae. 


\section{THE LEPTOSPORANGIATAE.}

When we seek to recognize the dominant phase in the life-history of the Leptosporangiatae, we have fortunately little difficulty. The evidence that, by Rhaetic times, this group had already attained to the status of a dominant factor in the flora is very clear. This position was also maintained in the Jurassic and Lower Cretaceous vegetations.

Of the Tertiary floras our knowledge unfortunately is very vague at present, but the fact that this line of descent is still one of the characteristic features of the vegetation of the world at the present day is proof that the broad phase of the life-line has continued more or less constant through a large number of geological periods. In other words, of the more ancient Mesozoic types, the Leptosporangiate Ferns, like the Coniferales, have on the whole been remarkably successful in the struggle for existence. Even at the present day they still maintain their position as an important element in the vegetation of the world side by side with other races, which attained to a position of dominance at a much later geological epoch.

In contrasting the Fern-like plants of the Palaeozoic and Mesozoic periods, one finds that, so far as their external morphology is concerned, those of the Mesozoic rocks seem to recall the recent Ferns even more closely than one might have expected. It may be admitted that, as regards the general configuration of the fronds, and certain other characters such as the circinate vernation, both the Palaeozoic and Mesozoic representatives agree in being exceedingly Fern-like. But such features are for the most part of little value phylogenetically. Young fronds coiled in a crozier-like manner, often referred to the frond-genus Spiropteris, Schimper ${ }^{1}$, where their real generic nature cannot be ascertained, are known from the Rhaetic as well as the Carboniferous rocks. In the latter case some have proved to belong to Neuropteris ${ }^{2}$, others to Pecopteris ${ }^{3}$. Among these, the Neuropterids at least were not Ferns, but Pteridosperms. Thus this type of vernation was common to more than one group in past times, just as to-day it is common to both Cycads and Ferns.

There are, however, some features of the Mesozoic Ferns which are sharply contrasted with those of the Fern-like plants of the Palaeozoic. In the earlier Mesozoic Floras, the pedate habit was undoubtedly a characteristic of the fronds of a number of true Ferns. Some of these families, the Matonineae and Dipteridinae, have still representatives living to-day, as Mr. Seward ${ }^{4}$ has shown. The type of sympodial branching exhibited by such a Fern-frond as that of the recent Matonia or the Jurassic Matonidium was not, however, the high-water mark in this direction. In Rhaetic times, as Nathorst ${ }^{5}$ has pointed out, we have still more complicated fronds. The

\footnotetext{
1 Schimper ('69), vol, i, p. 688, pl. 49, fig. 4.

${ }^{3}$ Kidston ('01), pl. 26, fig. I ; Potonié ('03), Pl. VIII.

4 Seward ('99), Seward and Dale ('01).

${ }^{2}$ Bunbury ('58), p. 243 , text-figure.

${ }^{5}$ Nathorst ('92), p. 169.
} 
frond of Camptopteris spiralis, Nath., for instance, exhibits a combination of the sympodial with the spiral type of branching in a very remarkable manner, a character which is also found, but to a much less extent, in certain leaves of the genus Dictyophyllum. Such features are quite unknown among the Palaeozoic Fern-like plants, and although among Mesozoic Ferns the frond is by no means always pedate, the frequent occurrence of this habit is significant.

Similarly the Palaeozoic Fern-like plants exhibit certain features which are more especially their own. Stress has been laid in more than one quarter on the occurrence of the repeatedly dichotomous type of branching ${ }^{1}$ found in many Palaeozoic fronds, and especially on the fact that stipular or adventitious outgrowths ${ }^{2}$, known as Aphlebiae, occur on the rachis in many cases. I am inclined to agree with a suggestion which was made recently by Professor Oliver that these features may probably be regarded as indicative of the fronds of members of the Pteridospermae rather than of true Ferns.

If, however, we turn to the subject of the fertile fronds of Mesozoic and Palaeozoic age, we are at once struck by the fact that, while such leaves, bearing annulate sporangia often but not always on fronds of unreduced lamina, are almost common in the Mesozoic sediments, such are comparatively rarely found in the older rocks. For instance, to take an example from our best-known British Mesozoic flora, Mr. Seward ${ }^{3}$ has described from the Lower Oolite of Yorkshire twenty species, regarded as probably of the nature of Ferns, and in thirteen cases the sporangia are known, which in eight or ten species are borne on fronds practically identical with the sterile foliage, and in three to five others on reduced fronds. Among the Palaeozoic Fern-like plants, the number of species, on the fronds of which annulate sporangia have been discovered, is, by comparison with the total number known, almost infinitely small.

Further it is clear from a study of the fertile fronds of Mesozoic age that, even by the Jurassic period, most of the modern families of ferns had become differentiated. Mr. Seward ${ }^{4}$ has recognized members of the Schizaeaceae, Osmundaceae, Cyatheaceae, Polypodiaceae, as well as of the Matonineae and Dipteridinae, in the rocks of that period.

It would be easy to discuss the Mesozoic Ferns at greater length, but enough has perhaps been said to show that, so far back as the Rhaetic period, Ferns belonging to modern families of Leptosporangiatae were not only in existence, but flourishing in sufficient degree to form one of the dominant features in the vegetation of that period.

\section{THE PRIMOFILICES.}

When, however, we try to trace the life-line of the Leptosporangiatae back to Palaeozoic times, we are at once in difficulties. A race which rose

\footnotetext{
1 Potonié ('95).

3 Seward ('00).
}

2 Potonié ('03).

4 Seward ('04), p. 843. 
to the position of a dominant factor in the vegetation of past or present times did not spring into existence abruptly, although in some cases it may have reached its dominant phase within a comparatively short geological period. It is true that, in the case of the Angiosperms, their advent certainly does appear to have been remarkably sudden, but one cannot help feeling that this conclusion, however much we may be driven to accept it on the present evidence, is really but the expression of our ignorance on the subject.

Our difficulties, as regards the Leptosporangiatae, are increased by the fact that there exists, at present, a considerable gap in our knowledge. Of all the geological periods from which some of the plant remains are known to us, two are especially interesting in that they represent the most critical epochs in the past history of the Vegetable Kingdom. The earlier of these covers the period in which the change from the Palaeozoic to the Mesozoic facies of plant-life took place. The latter holds the secret of the evolution of the Tertiary-Recent from the Mesozoic facies. How, during this latter period, this transition was effected we know practically nothing at the present moment. Of the earlier epoch, our knowledge is somewhat more satisfactory, but this flora stands in urgent need of correlation and critical revision, and until this has been accomplished, a gap in our knowledge, as I have said, will still exist. So far as one may judge from the present evidence, it would seem that the flora of the Upper Permian and Trias (excluding the Rhaetic) was probably a true Transition flora, in which the older Palaeozoic types gradually died out, and gave place to plants of a newer facies, which quickly rose to the position of dominant types in Mesozoic times. It may be that the thin, subsidiary, incoming-phase of the life-line of the Leptosporangiatae is chiefly to be sought for in the rocks of this transition period, of which at present we know so little. I do not propose, however, to attempt to trace here the evidence of the Leptosporangiate ferns in these sediments. Such will scarcely be possible until the critical revision, above suggested, has been effected.

If we pass back to the flora of the Carboniferous and Lower Permian, can we find any evidence of the Leptosporangiatae, either as a dominant or subsidiary factor in that vegetation? This question is by no means a new one. It has been discussed on many occasions, among them in a paper by Professor Bower ${ }^{1}$, published in I89I, in the fifth volume of the Annals. In the course of that contribution, which was in the main devoted to a consideration of such anatomical features of the modern Ferns as bear upon the question whether the Eusporangiate or the Leptosporangiate is the more primitive type of Fern, the author gave some account of the evidence derived from the fossil flora of the Palaeozoic Rocks. He concluded that 'though it is not possible absolutely to deny the presence of Leptosporan- 
giate Ferns in the primary rocks, still the evidences of their occurrence are at least exceedingly rare, and the question whether they existed at all in those early times is not even yet placed beyond the possibility of doubt by observation of microscopic sections.' These conclusions, at that time, were probably regarded as somewhat extreme, at least by those who were more especially concerned with the fossil evidence. At any rate, at the present time we know from more than one source, that annulate sporangia, which, in certain respects at least, may be somewhat closely compared with those of recent Leptosporangiatae, do occur in the Palaeozoic rocks. How far we are warranted, in the absence of any developmental evidence in the fossil state, in referring them to the Leptosporangiate Ferns, is a point which may now be considered in some detail.

The sources of evidence are threefold. In the first place certain impressions of Sphenopterid fronds have been described, sufficiently well preserved to permit of a detailed study of the sporangia which they occasionally exhibit. One of the best known of these, Hymenophyllites quadridactylites (Gutbier), the fertile fronds of which were described by Zeiller ${ }^{1}$, is generally held to be at least a Leptosporangiate Fern, and very possibly a member of the Hymenophyllaceae. Similarly the fructifications known as Oligocarpia and Senftenbergia, which are borne on fronds belonging to the form-genera Sphenopteris and Pecopteris respectively, are among others which appear to be, so far as structureless specimens will permit us to judge, of the nature of Leptosporangiate sporangia. But even if we regard some, at least, of these sporangia-bearing fronds as really Leptosporangiate Ferns, a conclusion which I am inclined to think is probably correct, it must at the same time be admitted that, in point of numbers, such plants were but few in Upper Palaeozoic times, and did not then form one of the dominant groups. I think it possible that, in some of these, we may recognize the beginnings of the thin, subsidiary phase of the life-line of Leptosporangiatae.

In the second place we have more satisfactory specimens, in which the structure is preserved. In both the Lower Coal Measures of England and the Permian of France, the calcareous or silicious nodules are found to contain, here and there, isolated sporangia or sori, for the most part not in obvious continuity with any other organ. Dr. Scott ${ }^{2}$ has recently described a striking case in which such sporangia contained spores which had begun to germinate within the sporangium. In this and other examples there is a well-marked annulus ${ }^{3}$. If, however, we closely compare these organs with those of a recent Leptosporangiate Fern, we shall find that they do not exactly agree in certain respects. For instance, as Dr. Scott has pointed out, we invariably find a bi- or multiseriate annulus in these fossils, as

\footnotetext{
1 Zeiller ('83). $\quad{ }^{2}$ Scott ('04).

${ }^{3}$ Exannulate sporangia also occur, vide Scott $\left({ }^{\prime} 05^{2}\right)$.
} 
opposed to the (with rare exceptions) uniseriate annulus of the recent Ferns. In another group, the Botryopterideae, this type of annulus is correlated with other features which are not found in modern Leptosporangiatae. It is better, therefore, to regard these usually detached sporangia with some suspicion as to their exact affinities.

And thirdly we have the evidence, from structure specimens, of the existence of a peculiar family, in Palaeozoic times, belonging to the Fern alliance - the Botryopterideae. The investigations of the late Bernard Renault $^{1}$ on these fossils, followed by those of Dr. Scott ${ }^{2}$, who was the first to point out clearly the affinities of this group, have shown that, although the Botryopterideae stand nearer to the modern Ferns than to any Palaeozoic group, yet they differ in certain important characters from any known Leptosporangiate Fern. It will not be necessary to enter here into the points of disagreement in detail. It may serve to mention the peculiar nature of the annulus and the fact that the wall of the sporangium is more than one layer in thickness, and to recall the unusual form and the size of the sporangia.

Bearing in mind such differences between these Palaeozoic sporangia and those of modern Leptosporangiatae as have been pointed out above, it would appear to me to be more helpful in our present difficulties with regard to the life-line of that race, as well as more consistent, not to attempt to bring these ancient Fern-like plants into line forcibly with the modern Ferns, however closely we may regard them as allied. Neither the Botryopterideae nor any of these isolated sporangia can be included in any recent family of the Ferns-a conclusion which is not disputed. It would seem much more likely that these fossils formed the only fragments which are at present known to us of an ancient Palaeozoic race. Professor Lignier ${ }^{3}$, in a recent contribution, has also come to what $I$ take to be a similar conclusion.

That this race gave rise to the Leptosporangiatae - using that term in the sense applied to the modern Ferns, and here also to the Mesozoic representatives - seems more than probable. Such a suggestion is not by any means new. Dr. Scott ${ }^{4}$, in his 'Studies', has clearly pointed out the synthetic nature of the Botryopterideae, 'in so far as they combine the characters of several of the existing families within this division,' i.e. Leptosporangiatae; 'and it is not improbable that they represent the stock from which some at least of the families were subsequently derived.' $\mathrm{Mr}$. Kidston ${ }^{5}$ has also arrived at a similar conclusion.

It has seemed to me that it would be convenient if this ancient race, of which, no doubt, the Botryopterideae were but one important family,

${ }^{1}$ Renault ('75).

${ }^{3}$ Lignier ('03), p. I03, and footnote; and p. I 33.

5 Kidston $\left(' 05^{2}\right)$, p. 162 .
${ }^{2}$ Scott ('00), chapter ix.

${ }^{4}$ Scott ('00), pp. 299, 506-9. 
were known by some special name. On a recent occasion I suggested the term Primofilices, in view of the fact that such, perhaps preferable, names as Archaeopterideae ${ }^{1}$ and Palaeopterideae are not available for this purpose. This term, although not altogether satisfactory, has the advantage of suggesting the Primary or Palaeozoic Age of the race.

One family of the Primofilices has already been recognized (the Botryopterideae), and possibly some at least of the detached annulate sporangia, known from structure specimens, belonged to other representatives. It seems probable that yet further examples will be discovered in the near future. On the other hand, certain of these Fern-like plants may have already begun to specialize along those lines which we see exhibited by the Mesozoic, Tertiary, and Recent Leptosporangiatae, and have thus become virtually members of that group. The evidence of some of the impressions mentioned above suggests that this may well have been the case. If, however, we admit the possibility that the Primofilices were the immediate forerunners of the Leptosporangiatae, the question as to whether Leptosporangiate Ferns existed in the Palaeozoic period becomes of minor importance. The ancestors naturally must be of much greater interest, at the present moment, than the first descendants of a race which we know so well in the living state.

One further conclusion should be borne in mind. Whether we regard the Botryopterideae as an ancient family, from which some of the Leptosporangiatae were later derived, or as a member of that group pure and simple, there can be no doubt that neither the Primofilices nor the Leptosporangiatae were, towards the close of the Palaeozoic period, in the position of dominant or ruling group, as compared with the Pteridospermae, or other of the great phyla, then at their maximum differentiation.

\section{The Eusporangiatae.}

When we turn to the geological evidence for the existence of the Eusporangiatae in past times, we have to deal with less trustworthy data. Until quite recently it has been generally held that this group of the Ferns was by far the most abundant and diversified in the Palaeozoic period. As Professor Bower expressed it in his paper, already referred to, 'recent writers have repeatedly remarked the preponderance of Ferns of the Eusporangiate type in primary rocks.' And again, 'where the sporangia have been found, they are in the overwhelming majority of cases of a character allied to the Marattiaceae ${ }^{2}$ ' In view, however, of the recent discovery by Mr. Kidston ${ }^{3}$ of the male organs of Lyginodendron, which have proved to be the fossils long known under the name Crossotheca, and

1 The term Archaeopterideae, suggested by Professor Lignier in this connexion (Lignier ('03), p. IO3 footnote) cannot hold good, as it is already in use for a Devonian family of Fern-like plants, including the genus Archaeopteris.

${ }^{2}$ Bower ('91), p. I 22.

${ }^{3}$ Kidston $\left({ }^{\prime} 05^{1}\right),\left({ }^{\prime} 05^{2}\right)$. 
which closely resemble the sporangia of recent Eusporangiate Ferns, this conclusion can no longer be held with the same confidence. How far it will be necessary to modify it, it is impossible to say at present.

We may again approach the problem by attempting to recognize in either the Palaeozoic or Mesozoic floras the broad phase of the life-figure of this race. We may first ask, Is there any evidence that the Eusporangiatae were a dominant group in the Rhaetic, Jurassic, or Wealden vegetations? So far as our present knowledge is concerned, this question can be answered by an emphatic negative. There is no member of these floras which can be regarded, with the least degree of probability, as allied to the family Ophioglossaceae. Further, it is difficult to recall more than a very few species which are or may be assigned to a position in or near to the Marattiaceae. Of these the best examples are to be found in certain fronds of Taeniopteris, occurring more especially in the Rhaetic and Liassic rocks.

The genus Taeniopteris is a frond-genus, including simple, entire, ribbon-like leaves, often of fairly large size, usually lanceolate or elliptical in form, with a well-marked midrib, and simple or occasionally dichotomizing lateral veins, which pursue a course almost at right angles to the midrib. This type of frond first appears in the Carboniferous and Permian floras of both the Northern and Southern Hemispheres, but it is more especially characteristic of the Rhaetic and other of the earlier Mesozoic floras. It can, of course, be closely matched among living Ferns, a consideration which is, however, of absolutely no value.

In the case of the widely distributed and characteristic Rhaetic species, Taeniopteris Münsteri, Goeppert ${ }^{1}$, fertile fronds have been discovered. The synangia borne on these fronds have, it must be confessed, so far as one can judge from impressions, a most striking resemblance to those of the modern Fern, Marattia. The discovery of such fertile examples of T. Mïnsteri in the Rhaetic rocks of Tonkin, led Professor Zeiller ${ }^{2}$ to go so far as to almost place this species within the recent genus. In the case of Swedish examples, which by the kindness of my friend Professor Nathorst I have recently had an opportunity of studying in Stockholm, the resemblance is equally striking.

Another, but in my opinion less satisfactory instance, is to be found in the genus Danaeopsis, Heer, and the species D. marantacea, Presl ${ }^{3}$, from the Triassic of Germany and elsewhere in Europe. The frond of Danacopsis may be roughly described as a pinnate frond, whose pinnae resemble the simple fronds of Taeniopteris. Here the synangia are said to recall more closely those of the recent genus Danaea, but I am not quite satisfied that this is the case.

${ }^{1}$ Nathorst (' $\left.78^{2}\right)$, p. 48, pl. I, fig. 6 (Höganäs yngre).

${ }^{2}$ Zeiller ('03), p. 63, pl. IX, figs. 6-8, as Taeniopteris (Marattia) Münsteri, Goeppert.

${ }^{3}$ Schimper ('69), vol. i, p. 614, pl. 37. 
There is a further impression from the Lias of Poland, named Danaea microphylla by Raciborski ${ }^{1}$, in which the resemblance to the recent fructification is, perhaps, rather closer.

Thus we find that although there is no evidence to show that the Eusporangiatae were a dominant group in Mesozoic times, there are apparently fairly good grounds for believing that this race was then in existence. But this conclusion, even on the present evidence, would have much greater weight than it appears to me to possess, were it not that there is at least a possibility, as yet to be disproved, that Taeniopteris itself may have been other than a true Fern. The suspicion that some of these Fern-like plants, possessing a fructification not unlike the synangia of a modern Eusporangiate Fern, may have been in reality the male organs of members of the Cycadophyta, is at the bottom of our present difficulties with regard to the past history of the Eusporangiatae, as will be seen when we come to discuss possible members of this group in Palaeozoic times. The fact that in the male fronds of the Pteridosperms, and in the same organs of the Bennettiteae ${ }^{2}$, a group directly descended from the Pteridospermae, as Dr. Scott ${ }^{3}$ has shown, the whole male fructification is strikingly like that of the modern Marattiaceae, cannot be overlooked in this connexion. Also we know that as early as the Rhaetic, some of the Cycadophyta bore seeds, after the manner of the modern genus Cycas. The specimen described by Nathorst ${ }^{4}$, from the Rhaetic of Bjuf, in Sweden, under the name Cycadospadix integer, Nathorst, which I have had the pleasure of seeing recently, appears to me to be conclusive in this respect. If this is so, we should certainly expect to find, among the earlier Cycadophyta, instances in which the male fructifications were not aggregated into cones, but borne on fronds, like the corresponding organs of the Pteridosperms. At the present time, no suspicion attaches to Taeniopteris in this connexion, but it is a possibility still to be borne in mind, and one which renders, in my opinion, the otherwise excellent evidence that this genus was a Eusporangiate Fern, rather less conclusive.

We know too little of the transition flora of the Palaeozoic and Mesozoic rocks to justify any attempt to seek for the Eusporangiate line of descent during that period at present. Raciborski ${ }^{5}$ has indeed stated that, in the Lunzer Schichten (Keuper) of Austria, the rich flora of which has unfortunately never been worked out, 70 per cent. of the Ferns belonged to the Marattiaceae, but I am not aware of the evidence for this statement. The possibility, however, remains, as I have hinted with regard to the Leptosporangiatae, that a further study of the plants of this transition period may throw important light on the Eusporangiate life-line.

When we turn to the Palaeozoic rocks, we find, as has been stated

1 Raciborski ('94), p. I3, pl. VI, figs. I-6.

${ }^{4}$ Nathorst ('02), p. 6, pl. I, fig. II.
2 Wieland ('01).

${ }^{5}$ Raciborski ('91). 
already, a large number of fructifications which have hitherto been regarded as undoubtedly belonging to Eusporangiate Ferns of the Marattiaceous type. Several of these have been referred to the fronds known under the names of Pecopteris and Sphenopteris. In some cases the sporangia are free from one another, though exannulate. Such occur on unreduced fronds in Dactylotheca (Pecopteris), Renaultea (Sphenopteris), and on reduced fronds in Urnatopteris (Sphenopteris). Or the sporangia are not only exannulate but united to form synangia. Examples, borne on unreduced fronds of the Pecopteris type, are found in Asterotheca, Scolecopteris, and Ptychocarpus ${ }^{1}$; on reduced fronds of the Sphenopteris type in Crossotheca ${ }^{2}$.

Less than a year ago Mr. Kidston ${ }^{3}$ showed that one of these fructifications, Crossotheca, was the male organ of a Pteridosperm (Lyginodendron). It is this discovery that has raised the present questions, Are all these fructifications the male organs of Pteridosperms? Did any of them really belong to the Eusporangiate Ferns?

It is obviously hopeless to try to answer these problems at the present stage. There are many indications that the Pteridosperms were a large and dominant group in Upper Palaeozoic times. So far we are acquainted with their male organs in only one case. There is considerable reason to suppose that, among the fructifications mentioned above, others will be found; in fact, it is difficult to imagine where else we are to look for such organs. Also it must be remembered that the male fructifications of the Bennettiteae ${ }^{4}$, the direct descendants of the Pteridosperms, were essentially similar to some of these Palaeozoic fructifications, and to those of the modern Eusporangiatae, as I have already indicated. Further, we know from an important discovery by M. Grand' Eury ${ }^{5}$ that at least one Pecopterid frond belonged to a Pteridosperm. No doubt P. Pluckeneti, among Pecopterids, did not stand alone in this respect. It is, therefore, not unnatural that suspicion should envelop some of the synangia mentioned above, which are borne on Pecopterid fronds.

On the present evidence, I am inclined to think that many others, besides Crossotheca, of these Marattiaceous-like, Palaeozoic fructifications will eventually prove to be the male organs of Pteridosperms. All such need not, however, have been of this nature ; but at the present moment it seems hopeless to try and distinguish between those which were, and those which were not Pteridospermic ${ }^{6}$. At any rate, there are no longer such strong reasons for believing that the Eusporangiate Ferns were a dominant type of Palaeozoic vegetation.

1 Figures of these fructifications will be found in Scott's 'Studies in Fossil Botany', and Zeiller's 'Éléments de Paléobotanique'.

${ }^{2}$ Mr. Kidston does not regard Crossotheca as consisting of synangia, but of bilocular sporangia.

${ }^{3}$ Kidston ('05'), ('05'). ${ }^{4}$ Wieland ('01).

${ }^{5}$ Grand' Eury ('05).

${ }^{6} \mathrm{Mr}$. Kidston ('05'), p. 162, however, regards Asterotheca as a Ensporangiate Fern, and concludes that, at the close of the Carboniferous period, the Marattiaceae assumed a very important place in this flora. 
It may be pointed out in this connexion that we have in the fructification of most of the modern Eusporangiate Ferns, as compared with the male organs of both the Palaeozoic Pteridosperms and the Mesozoic Bennettiteae, an interesting case of homoeomorphy. In each group, the sporangia, though dissimilar physiologically, are all exannulate, and more or less united into synangia, and they were all borne on fronds. Opinions will no doubt differ as to the precise significance attaching to this fact. Some may be inclined to regard it as indicating some degree of affinity between the Fern-line of descent and that of the Pteridosperms and Cycadophyta. Though affinity between these two life-lines at some remote geological period can hardly be doubted, I am not at all sure that this case of homoeomorphy implies a connexion between the Cycadean line of descent and that of the Eusporangiate Ferns in particular. These characteristics in common, though in dissimilar organs, may be simply due to parallelism of development, a frequent phenomenon in both the vegetable and animal kingdoms. Even in the case of organs of similar function in different groups, such similarities may be of little or no value as clues to affinities. For instance, in Palaeozoic times both the Pteridosperms and the Cordaitales, as well as some Lycopods, bore seeds; yet one would not, on this ground, claim that these groups must be nearly related. Exannulate synangia may well be an ancient type of fructification; but it does not follow that the life-line of the Eusporangiatae goes back to any distant geological period, because present members of the group also possess this feature. Thus it appears to me that the argument, based on the similarity of the male fructification of the Pteridosperm to the homosporous sporangium of modern Marattiaceae, can have little weight as a proof of the existence of the Eusporangiatae in Palaeozoic times, using the term in the sense applied to the modern Ferns.

But even if we are inclined to dismiss a large number, but not perhaps all, of the exannulate Palaeozoic sporangia from the Eusporangiatae, there is yet other proof of this line of descent in Carboniferous and Permian times, and one founded on the surer ground of structural anatomy. The well-known and very Fern-like stems included in the genus Psaronius are in the details, as well as in the general plan of their anatomy, strikingly like the modern Marattiaceae. A detailed comparison of their structure, as compared with the recent Ferns, on the part of Rudolph ${ }^{1}$, has recently emphasized this similarity even more clearly than before. Yet a puzzling feature connected with this type of stem is that certain Psaronii are known to have borne Pecopterid fronds, which in turn possessed an Asterothecalike fructification However, though it may appear difficult to reconcile this fact with conclusions already arrived at with regard to the fructifications discussed above, it may be readily admitted that, in the anatomy of

\footnotetext{
1 Rudolph ('05).
} 
the stem of Psaronius, we have features which undeniably indicate close affinity to the modern Marattiaceae. To Mr. Kidston ${ }^{1}$, who regards Asterotheca as above the suspicion of being a male organ of a Pteridosperm, this difficulty of course does not exist.

So far, we have discussed only those Palaeozoic fossils which resemble the modern Marattiaceae. Of the Ophioglossaceae we have, in the Primary rocks, almost as little trace as in the Secondary. There is, it is true, the Permian fossil from Autun in France, which Renault ${ }^{2}$ described under the name Ophioglossites antiquns, but the evidence for this attribution is extremely doubtful. So far as I am aware, not even a plausible case has been made out at present to show that the Ophioglossaceae occur in either the Mesozoic or the Palaeozoic rocks.

It will be seen, from what has been said above, that the task of tracing back the life-line of the Eusporangiate Ferns to the Palaeozoic period is beset by difficulties. There are at least some grounds for believing, either that they then existed, or that in the Palaeozoic rocks we are dealing with their direct ancestors. Which is the correct view we can hardly decide at present. It may be that in Palaeozoic times the Fern line of descent had not become clearly differentiated into Eusporangiate and Leptosporangiate. Dr. Scott ${ }^{3}$ has already suggested that the Botryopterideae combine characters common to the Ophioglossaceae and the Leptosporangiate Ferns. Possibly the origin of the Eusporangiatae is to be also sought for in the group which I have termed the Primofilices, of which the Botryopterideae are the best-known family at present. But until we know more of the exact nature of the Marattiaceous-like fructifications of the Palaeozoic rocks we are hardly in a position to speculate with advantage on these points, or to trace back the life-line of modern Eusporangiate Ferns with any certainty. One fact, however, stands out very clear. The evidence, formerly regarded as beyond suspicion, that the Eusporangiate Ferns formed a dominant feature of the vegetation of the Palaeozoic period, has been undermined, more especially by the remarkable discovery of the male organs of Lyginodendron by Mr. Kidston. At the best, we can only now regard them as a subsidiary group in that epoch in the past history of the vegetable kingdom.

\section{THE HydropterideaE.}

The remaining group, the Heterosporous Ferns, may be briefly dismissed. So far as I understand the evidence, there are no satisfactory grounds, at present, for believing that this race existed at all in Palaeozoic times. I am aware that statements to the contrary are numerous; in fact there exists a small literature on the subject of Palaeozoic Hydropterideae.

1 Kidston ('0 $\left.05^{2}\right)$, p. 162 .

${ }^{2}$ Renault ('96), p. 30, pl. 82, figs. 7, 9. 
But a close inquiry will show that such evidence as has been brought forward to support this attribution is by no means convincing. The fossils, whose claims to be regarded as members of this group have been so confidently urged by Dawson ${ }^{1}$ and Penhallow ${ }^{2}$ in Canada, and by Reid and Macnair ${ }^{3}$ in Scotland, are, curiously enough, among the oldest plants known to us, for they are derived from Devonian rocks. If the Hydropterideae really were, as has been insisted, a dominant race in that period, it is curious that we meet with no trace of them in the Lower or the Upper Carboniferous floras. But there are other objections, which are much more weighty. It has not, in my opinion, been demonstrated that the fossils, described as sporocarps by Dawson and others, have any real structural resemblance to those of the modern Water-Ferns. It may quite well be true that such bodies as Parka decipiens, Flem., are not typical sporangia. But they are not for that reason necessarily sporocarps. Also, in no case has any trustworthy evidence been found as to the nature of the plant which bore them. In some instances they have been attributed to certain stems occurring in the same beds, but it must be clearly understood that the evidence rests entirely on association alone, which in such cases is, by itself, of little or no value. There is also a total absence, among the fossils associated with these obscure fructifications, of plant remains, which could be regarded, by any stretch of the imagination, as in the least similar morphologically to members of the recent Salviniaceae or Marsiliaceae.

In the typical Mesozoic floras there are very few cases in which one would be led to suspect that any of the Fern-like plants should be assigned to this group. Certainly, there are no grounds at present for believing that the Hydropterideae were a dominant race in Mesozoic times. It is not until we reach the Angiospermous floras that we find definite traces of these Ferns. In one case, however, there does appear to be fairly good evidence for the conclusion that we may be dealing with a Mesozoic WaterFern. The genus Sagenopteris, a typical Rhaetic frond, and one which persisted until Wealden times, may have been of this nature. The form of the frond, composed of four leaflets springing from a common petiole, is not at all unlike that of Marsilia. In some species (e. g. S. alata, Nath.), as Nathorst ${ }^{4}$ has shown, the petiole is winged, and thus recalls a feature sometimes seen at the base of the stalk of the leaves of the recent genus. But a more important point is that impressions of fructifications, which certainly do resemble very strongly the sporocarps of the Water-Ferns, are sometimes found in association with the fronds of Sagenopteris. In the absence of any known instance in which a fructification of the Leptosporangiate type has been observed on the fronds of this genus, this association is distinctly suggestive. However, the affinities of this interesting

1 Dawson ('86) and ('88), chapter iii.

2 Dawson and Penhallow ('92).

3 Reid and Macnair ('99).

4 Nathorst ('78), p. 85 , pl. I, fig. I7; pl. XIX, fig. 4 . 
fossil must be considered for the present as ' not proven.' At any rate, we have better grounds for regarding Sagenopteris as possibly a member of the Hydropterideae, than in the case of any fossil known to us from the Palaeozoic rocks.

We see, therefore, that the Geological Record does not support the idea that the Heterosporous Ferns were, in any sense, an ancient race. On the present evidence, I am inclined to think that they branched off from the Homosporous Ferns, in all probability from the Leptosporangiate line of descent, during the Mesozoic period, with specialization to a hydrophilous habitat. As a concession to the necessities of their new environment they have evolved heterospory, but not that particular type of heterospory which we associate with a seed. In these Ferns we have a new line of development, a distinct type of heterospory, and one which, so far as I am aware, is a much more modern contrivance, in a geological sense, than the seed.

\section{General Conclusions.}

The main results which have been arrived at here are expressed diagrammatically in Figure I. The form of the life-line of the Leptosporangiatae is interesting in comparison with that of the Cycadophyta, which is also shown in the diagram. The absence of any broadening of the life-

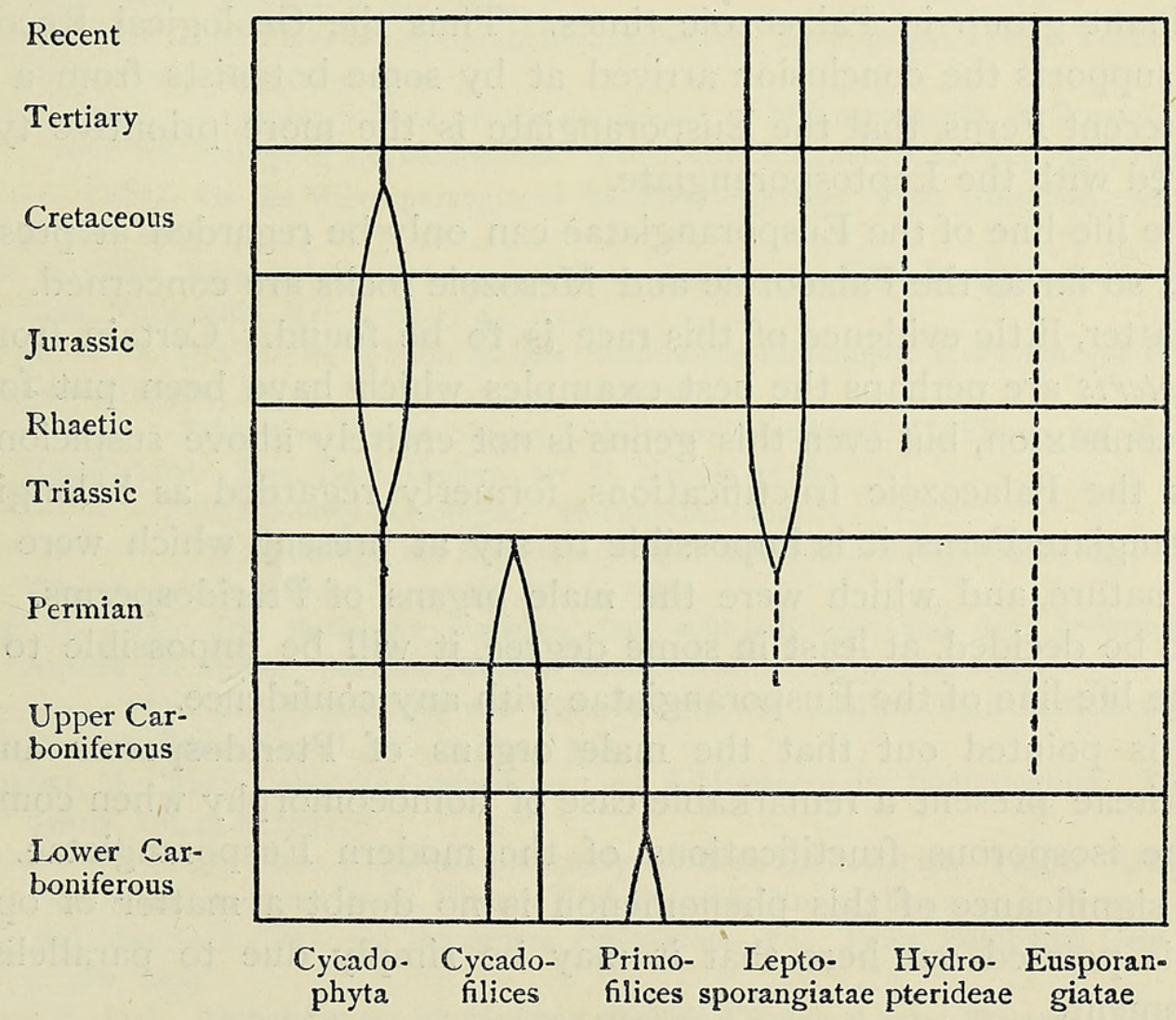

FIG. I. A diagrammatic representation of the Life-lines of the Ferns and certain other groups, showing the geological periods at which some of them attained to the position of dominant factors in the vegetation. 
figure in the case of the Eusporangiatae or of the Hydropterideae, such as would indicate a period or periods when these plants were in the position of dominant groups, is remarkable. The broken lines, in these and other cases, imply that the present evidence for the existence of such groups in certain geological periods is not entirely satisfactory.

As is already generally agreed, the Leptosporangiatae were, in the Mesozoic period, in the position of a dominant group, and most of the families still existing had then become differentiated.

But in the Palaeozoic period it seems doubtful if we can distinguish clearly between two groups, the Eusporangiate and the Leptosporangiate. It is more probable that the members of the Fern alliance, which then existed, although not in the later Palaeozoic forming a dominant group, were really an ancient stock, from which the Mesozoic Leptosporangiatae were derived. For this ancient group, the name Primofilices is suggested, and the Botryopterideae are regarded as being the, at present, best-known family within that group.

As the result of recent research on the nature of the male and female organs of the Cycadofilices, which has tended to show that many of the Fern-like fructifications occurring in the Palaeozoic rocks, formerly regarded as belonging to Eusporangiate Ferns, are more probably the male organs of Pteridosperms, it can no longer be held that the Eusporangiatae were a dominant group in Palaeozoic times. Thus the Geological Record no longer supports the conclusion arrived at by some botanists from a study of the recent Ferns, that the Eusporangiate is the more primitive type as compared with the Leptosporangiate.

The life-line of the Eusporangiatae can only be regarded at present as obscure, so far as the Palaeozoic and Mesozoic rocks are concerned. Even in the latter, little evidence of this race is to be found. Certain fronds of Taeniopteris are perhaps the best examples which have been put forward in this connexion, but even this genus is not entirely above suspicion. As regards the Palaeozoic fructifications, formerly regarded as belonging to Eusporangiate Ferns, it is impossible to say at present, which were really of this nature, and which were the male organs of Pteridosperms. Until this can be decided, at least in some degree, it will be impossible to trace back the life-line of the Eusporangiatae with any confidence.

It is pointed out that the male organs of Pteridosperms and the Bennettiteae present a remarkable case of homoeomorphy when compared with the isosporous fructifications of the modern Eusporangiatae. The precise significance of this phenomenon is no doubt a matter of opinion, but it is pointed out here that it may be simply due to parallelism of development.

As regards the Hydropterideae, there are no real grounds for believing, so far as the present evidence is concerned, that they existed at all in the 
Palaeozoic period. Even in the truly Mesozoic floras, the only example which can be put forward as a possible representative of this group is the genus Sagenopteris, and even here the case cannot be said to be proved.

In conclusion I would express my thanks to Dr. Scott for several suggestions embodied here, and for an opportunity of discussing these questions with him in some detail.

\section{BIBLIOGRAPHY .}

Bower, F. O. ('91): Is the Eusporangiate or the Leptosporangiate the more primitive type in the Ferns? Ann. Bot. v, p. Io9, I891.

Bunbury, C. J. F. ('58) : On a remarkable species of Neuropteris, \&c. Quart. Journ. Geol. Soc., xiv, p. 243,1858

Dawson, Sir William ('86): On Rhizocarps in the Erian (Devonian) Period in America. Bull. Chicago Acad. Sci., i, p. I05, I886.

('88): The Geological History of Plants. London, 1888.

Dawson, Sir W. and Penhallow, D. : Parka decipiens. Proc. and Trans. Roy. Soc. Canada, ser. 2 , ix, sect. iv, p. I, I 892 .

Grand' Eury, C. ('05): Sur les graines trouvées attachées au Pecopteris Pluckeneti, Schlot. Compt. Rend. Acad. Sci., cxl, p. 920 , I905.

Kidston, R. ('01) : The Flora of the Carboniferous Period. First Paper. Proc. Yorks. Geol. and Polyt. Soc., xiv, p. I 89 , I90I.

- $\left(05^{1}\right)$ : Preliminary Note on the occurrence of Microsporangia in Organic connexion with the Foliage of Lyginodendron. Proc. Roy. Soc., ser. B, lxxvi, p. 358, I905.

$\left(' 05^{2}\right)$ : On the Microsporangia of the Pteridosperms. Proc. Roy. Soc., ser. B, lxxvii, p. I6I, I905.

Lignier, O. ('03): Equisétales et Sphénophyllales. Leur origine filicinéenne commune. Bull. Soc. Linn. Normandie, sér. 5, vii, p. 93, 1903.

Nathorst, A. G. ('781): Om Floran Skånes Kolfo̊rande Bildningar. I. Floran vid Bjuf. Sver. Geol. Unders., ser. C, No. $27,33,35,1878-86$.

$\left(78^{2}\right)$ : Om Floran Skånes Kolforande Bildningar. II. Floran vid Höganäs och Helsingborg. Sver. Geol. Unders., ser. C. No. 29, I 878.

('92) : Sveriges Geologie. Stockholm, r892.

('02): Beiträge zur Kenntniss einiger mesozoischen Cycadophyten. K. Svensk. Vetenskaps-Akad. Handl., xxxviii, No. 4, I902.

РотоNí́, H. ('95): Die Beziehung zwischen dem echt-gabeligen und dem fiederigen WedelAufbau der Farne. Berichte Deutsch. Botan. Gesell., xiii, p. 244, I895.

('03): Zur Physiologie und Morphologie der fossilen Farn-Aphlebien. Berichte Deutsch. Botan. Gesell., xxi, p. I52, I903.

RAČıboRski, M. ('91): Ueber die Osmundaceen und Schizæaceen der Juraformation. Engler's Bo Jahrb., xiii, p. I, I89ז.

('94): Flora Kopalna ogniotrwalych Glinek Krakowskich. Part I. Archægoniatæ. Pamiet. matem-pryzr. Akad. Umiejt. Krakow, xviii, No. 3, I 894.

ReId, J. and MacnaIr ('99): On the genera Psilophyton, \&c. Trans. Edinburgh Geol. Soc., vii, p. 368, I 899 .

Renault, B. ('75): Recherches sur les végétaux silicifiés d'Autun et Saint-Étienne. Étude du genre Botryopteris. Ann. Sci. Nat. Bot., sér. 6, i, p. 220, and iii, p. 5, I875-6.

('96): Flore fossile du bassin houiller et permien d'Autun et d'Épinac. Part II. Études Gîtes Minér. France, 1896. 
RUdOLPH, K. ('05): Psaronien und Marattiaceen. Vergleichend anatomische Untersuchung. Denkschr. Math.-Nat. Cl. K. Acad. Wissensch. Wien, xxxviii, 1905.

Schimper, W. P. ('69): Traité de Paléontologie végétale. Paris, i, i869.

Scott, D. H. ('00): Studies in Fossil Botany. London, I90o.

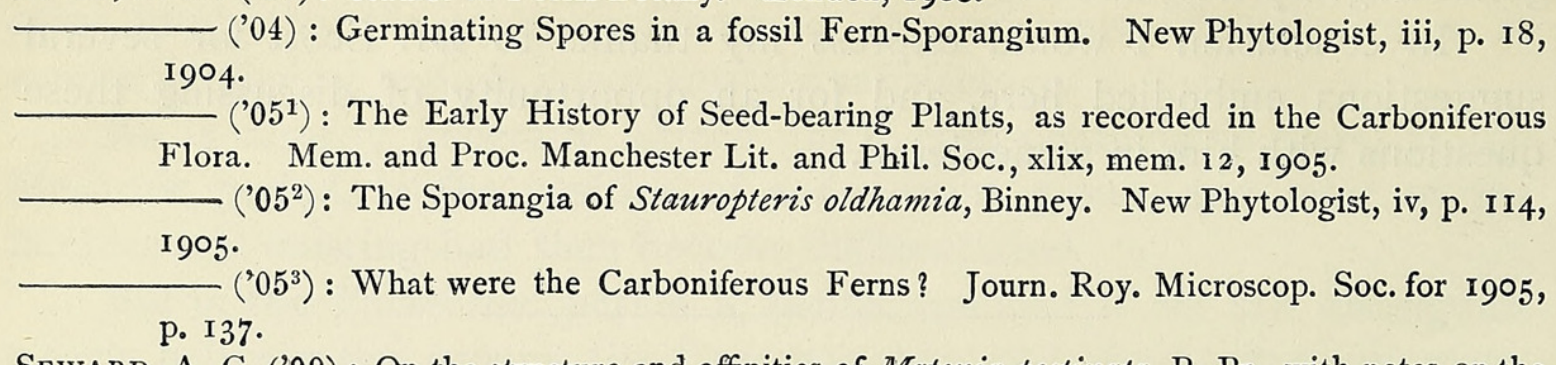

SEWARD, A. C. ('99): On the structure and affinities of Matonia pectinata, R. Br., with notes on the Geological History of the Matonineae. Phil. Trans. Roy. Soc., ser. B, cxci, p. I 7 I, I 899 . ('00): The Jurassic Flora. I. The Yorkshire Coast. Catalogue of the Mesozoic Plants in the Department of Geology ; British Museum. London, I900.

('04): Floras of the Past: their Composition and Distribution. (Presid. Address, Sect. K., Brit. Ass.) Report Brit. Ass. Southport (1903), p. 824, I904.

and DALE, E. ('01): On the Structure and affinities of Dipteris, with notes on the Geological History of the Dipteridinae. Phil. Trans. Roy. Soc., ser. B, cxciv, p. 497, I90I.

Wieland, G. R. ('01): A study of some American Fossil Cycads. Pt. IV. On the Microsporangiate Fructification of Cycadeoidea. Amer. Journ. Sci., xi, p. 432, I90r.

Zeiller, R. ('83) : Fructifications de Fougères du terrain houiller. Ann. Sci. Nat., sér. 6, xvi, p. $17 \%, 1883$.

('03): Flore fossile des gîtes de Charbon du Tonkin. Colonies françaises. Études Gîtes Minér. France, Text, I903, Atlas, 1902. 


\section{$2 \mathrm{BHL}$ Biodiversity Heritage Library}

Arber, E. A. Newell. 1906. "On the past history of the ferns." Annals of botany 20, 215-232. https://doi.org/10.1093/oxfordjournals.aob.a089095.

View This Item Online: https://www.biodiversitylibrary.org/item/234848

DOI: https://doi.org/10.1093/oxfordjournals.aob.a089095

Permalink: https://www.biodiversitylibrary.org/partpdf/318835

\section{Holding Institution}

Smithsonian Libraries

\section{Sponsored by}

Biodiversity Heritage Library

\section{Copyright \& Reuse}

Copyright Status: Not in copyright. The BHL knows of no copyright restrictions on this item.

This document was created from content at the Biodiversity Heritage Library, the world's largest open access digital library for biodiversity literature and archives. Visit BHL at https://www.biodiversitylibrary.org. 